\title{
Paulus se liggaam-metafoor in 1 Korintiërs 12 in literêr-historiese konteks
}

\author{
H Goede \& Fika J van Rensburg \\ Skool vir Bybelwetenskappe en Bybeltale \\ Noordwes-Universiteit (Potchefstroom Kampus)
}

\begin{abstract}
Paul's body metaphor in 1 Corinthians 12 in literary context

The purpose of this article is to place and describe Paul's use of the body metaphor in 1 Corinthians 12 in its literary context. By way of introduction, the importance of a proper understanding of Paul's use of the body metaphor is indicated. The first part of the article deals with the origin and use of the body metaphor in ancient times, thereby establishing the literary context within which Paul used the metaphor. Greek, Roman and Jewish usage is described. In the second part of the article the focus moves to Paul's use of the metaphor within its literary context. It is concluded that the body metaphor was well-known to Greek, Roman and Jewish readers, and was thus ideally suited to Paul's unique communication of the relationship between Christ and his church.
\end{abstract}

\section{INLEIDING}

Die doel van hierdie artikel is om Paulus se gebruik van die liggaam-metafoor in 1 Korintiërs 12 in literêr-historiese konteks te plaas en te beskryf. Die prominensie van die liggaam-metafoor in die erkende en betwiste ${ }^{1}$ Pauliniese briewe as beeldspraak vir die kerk van Christus, ${ }^{2}$ maak dit noodsaaklik dat gelowiges 'n behoorlike begrip daarvan het. Nie alleen verbeeld dit die verhouding waarin die kerk tot haar Hoof, Jesus Christus, staan nie, maar ook

\footnotetext{
${ }^{1}$ Die skrywers gaan nie verder in op die kwessie rondom die Pauliniese outeurskap al dan nie van die betwiste briewe nie, aangesien dit nie wesenlik 'n impak het op die oplossing van die probleemstelling van hierdie artikel nie.

${ }^{2}$ Vgl Rom 12:4-5; 1 Kor 10:17; 1 Kor 12:5; 12-20, 22, 25, 27; Ef 1:23; 2:16; 3:6; 4:4; 4:12; 4:15-16; 4:25; 5:23; 5:29-30; Kol 1:18; 1:24; 2:19; 3:15.
} 


\section{Paulus se liggaam-metafoor in 1 Korintiërs 12}

beeld dit die onderlinge verhouding tussen gelowiges as die lede van die liggaam uit. 'n Geldige interpretasie van hierdie liggaam-metafoor in die Pauliniese literatuur is dus noodsaaklik. Die feit dat Paulus so dikwels die liggaam-metafoor gebruik, laat die vraag ontstaan hoe verstaanbaar dit vir die eerste hoorders of lesers was. Hierdie vraag kan alleen beantwoord word met verwysing na die literêre konteks van 1 Korintiërs 12 . In die eerste deel van die artikel word die literêre konteks van 1 Korintiërs 12 bepaal met verwysing na die oorsprong en gebruik van die liggaam-metafoor in antieke tye, en in die tweede deel word Paulus se gebruik van die metafoor binne daardie literêre konteks geplaas.

\section{DIE OORSPRONG EN GEBRUIK VAN DIE LIGGAAM- METAFOOR IN ANTIEKE TYE}

Vir doeleindes van hierdie artikel word die volgende definisie van metafoor gebruik: Die essensie van metafoor is om een ding in terme van 'n ander te verstaan en te ervaar (Lakoff \& Johnson 1980:5). Die metafoor fokus die aandag op een aspek van 'n konsep, en terselfdertyd draai dit die fokus weg van ander aspekte wat teenstrydig met die metafoor is.

Martin (1995:6) waarsku tereg teen die lees van die liggaam-metafoor soos Paulus dit gebruik vanuit moderne konsepte oor die liggaam. Daarom is dit belangrik om konsepte rondom die liggaam en die gebruik van die liggaam as 'n metafoor in die tyd van Paulus te ondersoek. Die ontstaansgeskiedenis van die metafoor kan lig op Paulus se gebruik daarvan werp.

Die gebruik van die term "liggaam" ( $\sigma \hat{\omega} \mu \alpha)$ in die Nuwe Testament het sy oorsprong in die Griekse taal in die tyd toe die Nuwe Testament geskryf is (Bukas-Yakabuul 1986:62). Tog kan die invloed van die Romeinse en Joodse gebruik van die menslike liggaam as 'n model vir die eenheid van 'n gegewe groep mense of van die kosmos nie geïgnoreer word nie. Dit is daarom nodig om die gebruik van die liggaam-metafoor nie net in die Grieks-Romeinse wêreld te beskryf nie, maar ook in die Ou-Testamentiese en Joods-Christelike wêrelde.

\subsection{Die Ou Testament}

In die Ou Testament word 'n verskeidenheid van woorde vir die liggaam

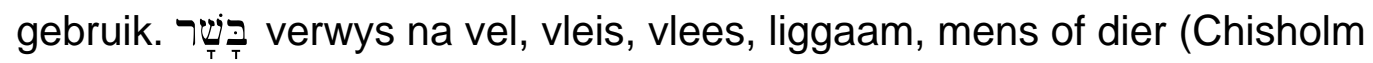

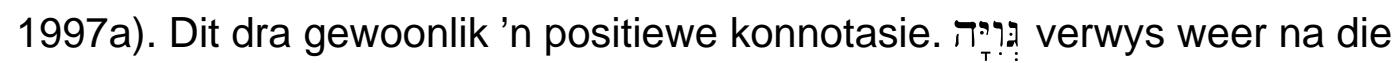
menslike of dierlike liggaam in lewende of dooie toestand (Alexander 1997).

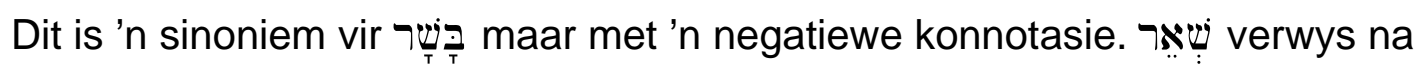


vleis, kos, vlees, liggaam, 'n bloedverwant en die self (Chisholm 1997b). Hierdie woord word in negatiewe en positiewe kontekste gebruik.

Die onderskeid tussen liggaam en siel, so eie aan die Griekse denke, kom nie in die Ou Testament voor nie (Schweizer 1992). Die mens word in die Ou Testament slegs holisties verstaan, as tegelyk sowel liggaam as siel. Die mens kan nie soos 'n spook siel sonder liggaam of soos 'n lyk liggaam sonder siel wees nie. Die Ou Testament stel ook nie belang in die mens as individuele persoon onderskeibaar van ander mense of as 'n klein heelal op sigself nie. Daarom is daar ook geen Ou-Testamentiese ekwivalent vir die Griekse $\sigma \hat{\mu} \mu \alpha$ nie (Schweizer 1992).

Daar is dus in die Ou Testament alleen sprake van korporatiewe persoonlikheid (Porthen 1991:33). Paulus kon dit oorspronklik in hierdie sin gebruik het, en toe gevul het met 'n inhoud afgelei uit wat Schweizer (1992) die Joodse korporatiewe patriargale denke noem). Deur die oorspronklike patriarg, Adam, is die mensdom in sonde gedompel (Schweizer 1992). Maar deur die patriarge Abraham, Isak en Jakob, word Israel die volk van God, en deur Jesus Christus word alle gelowiges deel van die nuwe volk van God. In hierdie sin is Jesus dus die patriarg en daarom die hoof van die liggaam.

\subsection{Die Griekse wêreld}

Die Griekse woord $\sigma \omega \hat{\mu} \alpha$ verwys primêr na 'n volledige lewende wese (BukasYakabuul 1986:77). In die klassieke tyd het dit na 'n lyk of karkas verwys, maar later het die verwysing verander na die borskas, die hele liggaam of die hele persoon (Motyer 1975:232). Hierdie spektrum van betekenisse word ook in die Nuwe Testament gevind (kyk 2.6).

Verskillende konsepte van die liggaam het in die Grieks-Romeinse wêreld bestaan (Martin 1995:36). Die volgende konsepte was prominent:

- Verskeie filosofiese beskouings van die liggaam waarvan almal minderheidsopinies was en nie as algemeen-geldend beskou kan word nie (Martin 1995:15).

- Die liggaam is beskou as 'n mikrokosmos (Martin 1995:16). Hierdie beskouing was nie metafories van aard nie maar is letterlik bedoel. Die grondslag van hierdie beskouing was die oortuiging dat 'n individu nie op sigself bestaan nie, dat die elemente waaruit die self bestaan, vloeibaar is, en dat daar 'n wesenlike kontinuïteit tussen die menslike liggaam en sy omgewing is (Martin 1995:21). 
- Die pneumatiese beskouing van die liggaam stel dat pneuma die agent van persepsie, beweging en die lewe self is (Martin 1995:21). Pneuma is die lewegewende materie vir die lede van die liggaam wat die liggaam voed.

- Veral onder die adellike klasse is die liggaam as 'n vormbare entiteit beskou (Martin 1995:25). Die liggaam van 'n babaseuntjie sou dan na geboorte gevorm kon word om aan die estetiese vereistes van sy sosiale klas te voldoen.

- Die liggaam is ook as 'n refleksie van die hiërargie van die samelewing beskou (Martin 1995:30). Die ledemate van die liggaam is beskou as agente of aspekte van sosiale ekonomie, en hulle interaksie is beskryf in terme van politieke stryd. Hier is sprake van sterker en swakker lede van die liggaam as refleksie van sterker en swakker lede van die samelewing (Martin 1995:32). Hierdie ongelykheid is as beide noodsaaklik en prysenswaardig aangedui, en is as argument teen rewolusie gebruik. Hoe kan die voet dan kop word (Martin 1995:93)? Titus Livius (Livius, Historiarum ab urbe condita 2.32.8-12) se weergawe van die fabel oor die maag en ledemate getuig van hierdie beskouing (kyk hieronder by 2.3).

- Die liggaam is ook in terme van skoonheid en volmaaktheid beskou (Martin 1995:34). Die volmaakte liggaam besit goddelike skoonheid en het geen swakheid, gewoonheid of lelikheid nie. Hierteenoor is die volmaakte liggaam ook as 'n balans tussen twee onaanvaarbare uiterstes gesien (Martin 1995:35). Die grondslag hiervan was 'n ideologie van matigheid en die (goue) middeweg. Geen liggaamsdeel moet te groot of te klein wees nie.

Plato ( $\mathrm{Pl}$, Resp 462c) het die liggaam-metafoor gebruik om na die eenheid van 'n stad en die rol van die verskillende dele daarvan in daardie eenheid te verwys. Plato gebruik die woord $\sigma \hat{\omega} \mu \alpha$ in sy primêre betekenis naamlik as menslike liggaam in sy lewende toestand (Bukas-Yakabuu, 1986:79). Die term $\sigma \omega \hat{\omega} \mu \alpha$ was ook goed bekend in populêre Hellenistiese filosofie as aanduiding van 'n gemeenskap (Porthen 1991:30). Die Stoïsyne het die metafoor as uitdrukking van eenheid gebruik, maar dan met verwysing na die eenheid van die kosmos en die eenheid van die mensdom (Schweizer 1992). Die metafoor is eers ná die tyd van Paulus gebruik om 'n groep mense te identifiseer (Wikenhauser 1937:122). 
Lee (2006:23) beskou Stoïsisme as 'n uiters belangrike konteks vir die verstaan van die liggaam-metafoor in 1 Korintiërs 12 . Die heelal is voorgestel as 'n liggaam en 'n lewende wese wat verenig word deur $\pi \nu \varepsilon u ̂ \mu \alpha$, en deur

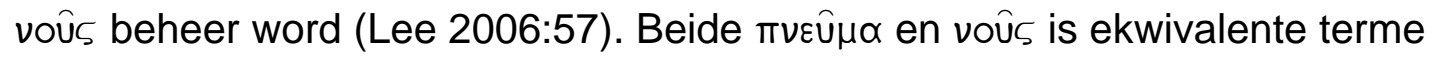
vir "God". Die idee van 'n liggaamlike heelal is toegepas op 'n liggaamlike eenheid van die mensdom en die gode, en is as die basis vir die Stoïsynse etiek gebruik (Lee 2006:101). Morele opvoeding het gefokus op die feit dat die individu aan hierdie universele mensdom behoort en hoe hierdie feit tot spesifieke etiese besluite moes lei. Omsien na die self sluit ook omsien na die res van die mensdom in.

Paulus moedig die Korintiërs aan om geestelike gawes in die lig van liggaamlike eenheid te beskou (Lee 2006:151). En as lede van hierdie nuwe, verenigde liggaam het die gelowiges sekere etiese pligte. Hierdie etiese pligte kan egter alleen uitgevoer word as die gemeente die voûs Xpıбтoû toepas, dit is die kruis van Christus soos uiteengesit in 1 Korintiërs 1-4 (Lee 2006:166). Paulus se gebruik van die liggaam-metafoor gaan dus verder as blote vergelyking om uiteindelik die gemeente se identiteit te beskryf (Lee 2006:198). Die Stoïsynse konteks van Paulus se gebruik van die liggaammetafoor kan nie ontken word nie, maar moet nie tot enigste konteks verhef word nie. Lee (2006:23) gee dit ook toe.

Verder moet die verskille tussen Paulus en die Stoïsyne ook uitgewys word. Twee verskille in die Stoïsynse en Pauliniese gebruik van die metafoor val op:

- In populêre Hellenistiese filosofie behoort individuele lede ter wille van die groter groepsbelang op te tree (Porthen 1991:31). In Pauliniese gebruik is goeie of korrekte optrede tussen lede onderling egter 'n gawe van die Gees gewortel in die Hoof van die liggaam, Jesus Christus (1 Kor 12:7; Ef 4:15-16).

- Die eenheid van die liggaam vind volgens Hellenistiese filosofie sy oorsprong in die natuur (Porthen 1991:31). Paulus vind egter die oorsprong van die eenheid in die kruis en opstanding van Jesus Christus, met die eskatologiese perspektief dat die gelowige liggaamlik soos Jesus se liggaam sal word (Rom 8:29; Fil 3:21).

Beide elemente van Plato se gebruik van die metafoor, naamlik eenheid en interafhanklikheid vind mens ook in Paulus se gebruik daarvan. Die gedagte van "liggaam" met sy funksionele lede is in fokus, en dit is die kern van die 


\section{Paulus se liggaam-metafoor in 1 Korintiërs 12}

liggaam-metafoor in die situasies waaroor Paulus skryf. Metafories beskou, dien die menslike liggaam as 'n lewende model vir eenheid, koördinasie en afhanklikheid (Bukas-Yakabuul 1986:78).

\subsection{Die Romeinse wêreld}

Corpus verwys in die algemeen na enige voorwerp saamgestel uit materiale wat deur die sintuie waargeneem kan word (Lewis \& Short 1907:472). Meer spesifiek verwys dit letterlik na die liggaam en substansie teenoor die animus. Die liggaam kan lewend of dood wees en na dié van 'n mens of ' $n$ dier verwys. Metafories verwys dit na 'n geheel wat uit verenigde dele bestaan, 'n struktuur, gemeenskap of korporasie (Lewis \& Short 1907:473).

Onder die Romeine is die fabel van die maag en die liggaamsdele 'n klassieke voorbeeld van die gebruik van die liggaam-metafoor voor, gedurende en na die tyd van Paulus (Bukas-Yakabuul 1986:66). Hierdie beeld kom met variasies in ander klassieke werke voor, en daar is ook parallelle met dit wat in die briewe van Paulus gevind word (Ogilvie 1965:312). Die gebruik van die beeld fokus op die rol van elke ledemaat as deel van die geheel (Livius, Historiarum ab urbe condita 2.32.8-12). Die fabel handel oor die ledemate van die liggaam wat hulle vir die maag vererg het. Al hulle arbeid was ingestel op die welsyn van die maag wat die vrug van hierdie arbeid geniet het, maar geen bydrae gelewer het nie. Daarom kom die ledemate ooreen om die maag deur hongersnood tot oorgawe te dwing, met die gevolg dat die hele liggaam tot die uiterste uitgemergel geraak het. Hoewel die ledemate dit nie kon sien nie, was die maag werksaam om voedingskrag na alle dele van die liggaam te versend.

Daar word dus dramaties uitgebeeld wat die gevolge van afskeiding of die eensydige najaag van individuele belange is: die gesondheid van die hele liggaam word geaffekteer (Bukas-Yakabuul 1986:82). Terselfdertyd het die verdeeldheid egter ook 'n positiewe gevolg, naamlik dat die ledemate bewus word van die feit dat hulle in die liggaam saamgebind is, en wat die samebindende faktor tussen hulle is. Paulus se gebruik van die liggaammetafoor fokus sterk op hierdie aspek, iets wat in die klassieke gebruik onderbeklemtoon word (Bukas-Yakabuul 1986:83).

\subsection{Die Gnostiese mitologie}

Die Gnostiese mitologie ken uitbeeldings van 'n verlosser as iemand met 'n massiewe liggaam waarin die siele van die verlostes, die uitverkorenes, ingesluit is (Porthen 1991:32). Volgens dié mite sou die goddelike oermens met 'n massiewe liggaam na die aarde gekom het waar hy in die stoflike wêreld gevange gehou is. Slegs deel van hom kon uit die gevangeskap 
ontsnap sodat fragmente van sy liggaam agtergebly het. Ten einde hierdie fragmente te verlos, moes die oermens weer na die aarde terugkeer om die reddende kennis mee te deel. Sodoende is die fragmente in staat gestel om hulself te bevry en met sy liggaam herenig te word. Die mite het egter eers in die derde eeu na Christus ontstaan (Porthen 1991:33), en kan daarom nie as direk relevant vir Paulus se gebruik van die liggaam-metafoor beskou word nie.

\subsection{Die Joodse wêreld tydens die vroeë Christendom}

Josephus (Jos, BJ 4.406) en Philo (Philo Plant 7) bevat voorbeelde van die gebruik van die liggaam-metafoor onder Jode. In hierdie voorbeelde verbeeld die metafoor ook eenheid onder mense of die eenheid van die heelal. Met die metafoor stel Josephus (Jos, BJ 4.406) die Joodse volk voor wat as eenheid deur oorlog geraak word, al sou sommiges nader aan die voorste linies wees as ander.

\section{6 "Liggaam" in die Nuwe Testament}

In die Nuwe Testament is die Ou-Testamentiese holistiese beskouing van die mens dominant, hoewel die Griekse woord $\sigma \hat{\omega} \mu \alpha$ gebruik word (Schweizer 1992). Die hele mens, liggaam en siel, sal tussen die dooies uit opgewek word. En tog word die liggaam uitgesonder as die tempel van die Heilige Gees en die lewende offer van die gelowige as die wesenlike van sy godsdiens. Die liggaam behoort dus spesifiek ook aan Christus.

Die liggaam van Christus verwys in die eerste plek na Christus self wat gekruisig is (Rom 7:4; Kol 1:22) en na die inlywing van gelowiges in Hom (1 Kor 12:12-13, 27). Wanneer Paulus dus van die liggaam van Christus praat, verwys hy na die feit dat die gelowiges "in Christus" is: die gemeenskap van gelowiges met Christus en deur Hom met God is primêr, terwyl die gemeenskap met individuele lede sekondêr is (Schweizer 1992).

$\Sigma \hat{\omega} \mu \alpha$ kom in vyf semantiese domeine voor (Louw \& Nida 1988b:240), naamlik 8, 9, 11, 58 en 87. Die eerste domein (8) bevat elemente wat oor die liggaam, liggaamsdele en uitskeidings van die liggaam handel. Hierdie woord val binne die subdomein "liggaam" (A). Dit is ook die vertaalmoontlikheid wat Louw \& Nida (1988a:93-94) voorstel. "Liggaam" verwys na die fisiese liggaam (lewend of dood) van persone, diere of plante. Hierdie subdomein word van twee ander onderskei naamlik "liggaamsdele" en "fisiologiese produkte van die liggaam". $\Sigma \hat{\omega} \mu \alpha$ is weer duidelik van hierdie subdomeine te onderskei aangesien dit na die hele liggaam verwys, en nie 'n deel daarvan nie. Verder is die liggaam bron van enige fisiologiese produk, en dus nie self produk nie. 
Die subdomein "liggaam" (A) bevat 'n hele aantal terme vir die liggaam wat duidelik van mekaar onderskei moet word (Louw \& Nida 1988a:93-95). 'n Ontleding van die verskille lyk soos volg:

\begin{tabular}{|c|c|c|c|c|c|c|c|c|}
\hline & $\begin{array}{c}8.1 \\
\sigma \hat{\omega} \mu \alpha\end{array}$ & $\begin{array}{c}.2 \\
\sigma \omega \mu \alpha T I K o ́ s\end{array}$ & 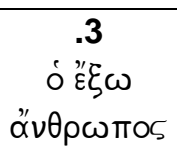 & $\begin{array}{c}.4 \\
\sigma \alpha ́ \alpha \xi\end{array}$ & $\begin{array}{c}.5 \\
\text { бKñvos }\end{array}$ & 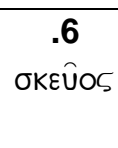 & $\begin{array}{c}.7 \\
\pi \tau \hat{\omega} \mu \alpha\end{array}$ & $\begin{array}{c}.8 \\
\kappa \hat{\omega} \lambda \circ v\end{array}$ \\
\hline $\begin{array}{l}1 \text { Die fisiese } \\
\text { liggaam van } \\
\text { mense, diere of } \\
\text { plante (lewend } \\
\text { of dood) }\end{array}$ & $X$ & & & & & & & \\
\hline $\begin{array}{l}2 \text { Wat in verband } \\
\text { met die fisiese } \\
\text { of liggaamlike } \\
\text { staan }\end{array}$ & & $\bar{X}$ & & & & & & \\
\hline $\begin{array}{l}3 \text { Fisiese vorm } \\
\text { van 'n mens }\end{array}$ & $X$ & & $X$ & & & & & \\
\hline $\begin{array}{l}4 \text { Lewende } \\
\text { liggaam }\end{array}$ & $\bar{X}$ & & & $\bar{X}$ & & & & \\
\hline $\begin{array}{l}5 \text { Liggaam as 'n } \\
\text { tydelike } \\
\text { woonplek }\end{array}$ & & & & & $X$ & & & \\
\hline $\begin{array}{l}\text { Seksualiteit van } \\
\text { die liggaam }\end{array}$ & & & & & & $X$ & & \\
\hline $\begin{array}{l}7 \text { Dooie liggaam } \\
\text { van 'n mens of } \\
\text { dier }\end{array}$ & $X$ & & & & & & $\bar{X}$ & \\
\hline $\begin{array}{l}8 \text { Dooie liggaam } \\
\text { van 'n mens }\end{array}$ & $X$ & & & & & & $X$ & $\bar{X}$ \\
\hline
\end{tabular}

$\sum \hat{\omega} \mu \alpha$ (8.1) blyk dus 'n oorkoepelende term vir enige lewende of dooie liggaam te wees. Die ander woorde in die subdomein verteenwoordig meer gefokusde betekenisse binne die betekenisveld van $\sigma \omega \hat{\mu \alpha \alpha}$.

Die tweede semantiese domein (9) dui mense aan (Louw \& Nida 1988a:104). $\Sigma \omega \hat{\mu \alpha \alpha}(9.8)$ word hier gebruik met 'n figuurlike betekenis wat op die wese van die mens in sy fisiese toestand dui. Uit die konteks van 1 Korintiërs 12 blyk dit dat hierdie betekenis nie relevant is nie, en daarom word nie verdere aandag daaraan geskenk nie.

Die derde semantiese domein (11) dui op groepe en klasse mense, asook lede van sodanige groepe en klasse (Louw \& Nida 1988a:121). Hierdie domein bevat vyf subdomeine naamlik algemene klasseverdelings (A), sosiogodsdienstige groepe of klasse (B), sosio-politieke groepe of klasse (C), etnies-kulturele groepe of klasse (D) en filosofiese groepe of klasse (E). Louw \& Nida (1988a:121) dui in die inleiding tot die domein aan dat daar verskeie 
gevalle van oorvleueling tussen die subdomeine is en dat hierdie indeling dus nie as waterdig beskou moet word nie. Dit word duidelik as mens daaraan dink dat mense tog nie net in sosio-politieke of -godsdienstige verhoudings staan nie maar in al die kategorieë van groepe of klasse wat aangedui word.

$\Sigma \hat{\omega} \mu \alpha(11.34)$ val onder subdomein B, naamlik sosio-godsdienstige groepe of klasse. Aangesien Paulus die kerk as die liggaam van Christus beskryf (1 Kor 12:12), is $\sigma \hat{\omega} \mu \alpha$ in hierdie betekenis van pas, en nie in enige van die ander subdomeine nie. Die feit dat Paulus die gemeente van Christus in Korinte onderrig, beperk die studie van woorde binne die subdomein tot dié wat die gelowiges as sosio-godsdienstige groep identifiseer.

\begin{tabular}{|c|c|c|c|c|}
\hline & $\begin{array}{c}11.31 \\
\text { Пoí } \mu \nu ı v v\end{array}$ & $\begin{array}{c}.32 \\
\varepsilon \kappa k \lambda \eta \sigma^{\prime} \alpha\end{array}$ & 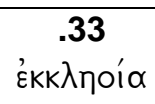 & $\begin{array}{c}.34 \\
\sigma \hat{\omega} \mu \alpha\end{array}$ \\
\hline $\begin{array}{l}\text { Volgelinge van Christus as ' } n \\
\text { gedefinieerde groep mense }\end{array}$ & Christus & $X$ & $\mathrm{X}$ & $\bar{X}$ \\
\hline $\begin{array}{l}2 \text { 'n Plaaslike kerk van Christus bv. in } \\
\text { Korinte }\end{array}$ & & $X$ & & $X$ \\
\hline $\begin{array}{l}3 \text { Die algemene kerk van Christus (al die } \\
\text { plaaslike kerke) }\end{array}$ & & & $X$ & $X$ \\
\hline $\begin{array}{l}4 \text { Volgelinge van Christus saamgebind as } \\
\text { 'n groep met die implikasie van } \\
\text { onderskeidende funksies in die groep }\end{array}$ & & & & $X$ \\
\hline
\end{tabular}

Die ontleding dui aan dat $\sigma \hat{\omega} \mu \alpha$ na die kerk van Christus in plaaslike en universele sin verwys. Die plaaslike kerk is die liggaam van Christus, maar die kerk as geheel van alle uitverkorenes is ook die liggaam van Christus. Die kerk as liggaam van Christus impliseer egter dat die Gees aan elke ledemaat van die liggaam (of dan lidmaat van die kerk) gawes gee om 'n bepaalde funksie in die liggaam (kerk) te verrig. Hierdie betekenis is duidelik in 1 Korintiërs 12 ter sprake.

Die vierde semantiese domein (87) waarbinne $\sigma \hat{\mu} \mu \alpha$ voorkom, dui op status (Louw \& Nida 1988a:734). Hier val die woord in die subdomein "slaaf, vry" (E). Die konteks van 1 Korintiërs 12 sluit egter hierdie interpretasie uit. Dieselfde kan gesê word van die vyfde domein (58) wat op die natuur, klas en voorbeeld fokus (Louw \& Nida 1988a:585). Hier val $\sigma \omega \hat{\mu} \mu$ in die subdomein "argetipe, ooreenstemmende tipe (anti-tipe)" (J). Weereens sluit die konteks van 1 Korintiërs 12 sodanige interpretasie uit.

Samevattend: $\sigma \hat{\omega} \mu \alpha$ word met twee betekenisse in 1 Korintiërs 12 gebruik. Eerstens verwys dit na die fisiese liggaam van die mens as voorstelling in Paulus se gebruik van die liggaam-metafoor, en tweedens na die kerk (plaaslik en/of universeel) as liggaam van Christus. 
Paulus se liggaam-metafoor in 1 Korintiërs 12

\subsection{Die liggaam-metafoor as oorspronklike Pauliniese skepping}

Voorstanders van die gedagte dat die liggaam-metafoor as verbeelding van die kerk se verhouding met Christus en onderlinge verhoudings tussen lede oorspronklik Paulinies is, hou drie teorieë ${ }^{3}$ voor:

- Die eerste teorie stel dat Paulus se gebruik van die liggaam-metafoor gegrond is in sy se Damaskus-ervaring (Jewett 1971:245). Christus se woorde aan Paulus ${ }^{4}$ impliseer volgens hierdie teorie dat Christus implisiet die kerk met Homself identifiseer. Volgens Jewett (1971:246) is die tekortkoming van die teorie dat die term $\sigma \hat{\omega} \mu \alpha$ nie deur Christus gebruik word nie, en Christus se woorde dus nie as bron vir die gebruik van die liggaam-metafoor deur Paulus aangedui kan word nie.

- Die tweede teorie lui dat die metafoor bloot 'n alternatiewe vorm vir die

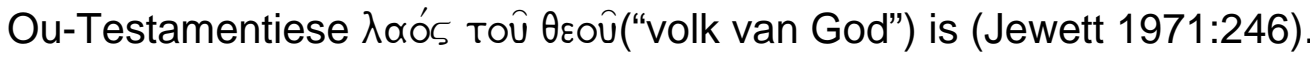
Die teorie moet egter bevraagteken word aangesien Paulus self nooit die term in enige van sy briewe gebruik nie.

- Die derde teorie stel dat Paulus die konteks van sy gebruik van die liggaam-metafoor in die eenheid van gelowiges met Christus deur die sakramente vind (Jewett 1971:247). Hy identifiseer immers in 1 Korintiërs 11:29 die tekens van brood en wyn by die nagmaal met die liggaam en bloed van Christus. Volgens dié teorie dui dit daarop dat Paulus die tekens werklik as die liggaam en bloed van Christus beskou, met die gevolg dat die gelowige liggaamlik met Christus verenig word. Jewett (1971:247) meen egter tereg dat daar geen konkrete bewys hiervoor is nie.

Jewett (1971) se beoordeling van bogenoemde teorieë hou water. Dit sluit egter nie die moontlikheid uit dat die liggaam-metafoor as verbeelding van die kerk se verhouding met Christus en onderlinge verhoudings tussen lede oorspronklik Paulinies is nie.

\footnotetext{
${ }^{3}$ Jewett (1971:245-248) gee 'n oorsig oor die drie teorieë. Sy samevatting is voldoende vir die doeleindes van hierdie studie.

${ }^{4}$ Handelinge 9:4: "Saul, Saul, waarom vervolg jy My?" (NAB).
} 


\section{PAULUS SE GEBRUIK VAN DIE LIGGAAM-METAFOOR}

Die studie van metafore en metafoorteorie is wesenlik vir 'n begrip van wat Paulus met die liggaam-metafoor wil oordra, aangesien die liggaam-metafoor baie sentraal by Paulus is, en al as die sentrum van sy se teologie beskryf is (Porthen 1991:11). Die liggaam speel inderdaad so prominente rol in Paulus se briewe dat Sandnes (2002:212) na Paulus se teologie verwys as die liggaam van die liggaam. In totaal kom die woord $\sigma \omega \hat{\mu} \alpha$ en stamverwante woorde 94 keer in die Pauliniese geskrifte voor, en wel met die volgende verspreiding:

\begin{tabular}{|c|c|c|c|}
\hline \multirow[t]{2}{*}{ Brief } & \multicolumn{3}{|c|}{ Aantal voorkomste } \\
\hline & $\sigma \hat{\omega} \mu \alpha$ & Stamverwante woorde & Totaal \\
\hline Romeine & 13 & 0 & 13 \\
\hline 1 Korintiërs & 46 & 0 & 46 \\
\hline 2 Korintiërs & 10 & 0 & 10 \\
\hline Galasiërs & 1 & 0 & 1 \\
\hline Efesiërs & 9 & 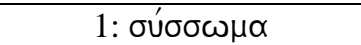 & 10 \\
\hline Filippense & 3 & 0 & 3 \\
\hline Kolossense & 8 & 1: $\sigma \omega \mu \alpha T I K \hat{\omega} S$ & 9 \\
\hline 1 Tessalonisense & 1 & 0 & 1 \\
\hline 2 Tessalonisense & 0 & 0 & 0 \\
\hline 1 Timoteus & 0 & 1: $\sigma \omega \mu \alpha \mathrm{TIKI}$ & 1 \\
\hline 2 Timoteus & 0 & 0 & 0 \\
\hline Titus & 0 & 0 & 0 \\
\hline Filemon & 0 & 0 & 0 \\
\hline
\end{tabular}

Juis in 1 Korintiërs is Paulus se gebruik van die liggaam-begrip en -metafoor dus van besondere belang, soos blyk uit die relatiewe hoë frekwensie.

\subsection{Pauliniese briewe in die algemeen}

'n Ontleding van die gebruik van die woord $\sigma \omega \hat{\mu \alpha}$ in Paulus se briewe dui aan dat ongeveer die helfte van die verwysings in oproepe te vinde is. In 1 Tessalonisense, Galasiërs, Filippense en die eerste deel van 1 Korintiërs tot by 9:27 word $\sigma \omega \mu \alpha$ selde gebruik. Waar dit wel gebruik word, verwys dit na die waarneembare menslike liggaam (vgl Porthen 1991:36-37).

In 1 Korintiërs vanaf 9:27 ontwikkel twee tegniese gebruike van die woord: eerstens as die basis van verwantskap tussen en eenheid van persone en tweedens vir die kerk as liggaam van Christus. Paulus poog om met hierdie gebruike van die somatiese beeld ' $n$ realistiese beskrywing van die eenheid van die kerk te gee (vgl Porthen 1991:37). In Romeine word die woord slegs in die eerste tegniese sin (die basis van verwantskap tussen en eenheid van persone) gebruik, en glad nie as ekklesiologiese term nie. 


\section{Paulus se liggaam-metafoor in 1 Korintiërs 12}

\subsection{Korintiërs 12-14}

In 1 Korintiërs 12 - 14 word Christus met die hele liggaam vergelyk, en nie alleen met die hoof soos in Efesiërs en Kolossense nie (Bukas-Yakabuul 1986:265). Die identifikasie van Christus met die hele liggaam (die lyf én kop) fokus moontlik meer op die probleme in die gemeente in Korinte, terwyl die identifikasie van Christus met nét die kop van die liggaam weer op die kosmiese dimensie van Christus se Hoofskap fokus.

Paulus se sogenaamde teologie van die liggaam is gewortel in sy vaste hoop op 'n liggaam selfs in die lewe hierna (Sandnes 2002:212). Dit word duidelik uit 1 Korintiërs 15. Die toekomstige transformasie van die liggaam veronderstel sekere morele eise vir die elkedagse lewe van die gelowige duskant die graf. Die basis van hierdie toekomstige transformasie is die opstanding van Jesus Christus en die verwagte opstanding van die gelowiges. Dit is in hierdie konteks dat Paulus se oproepe oor die eet van vleis wat aan afgode geoffer is, seksuele sondes en die gepaste gebruik van die nagmaal gesien moet word (Sandnes 2002:212). Paulus stel die heiligheid van die liggaam teenoor die genotsug van die ongelowige wêreld.

Alhoewel 1 Korintiërs 12-14 nie as geheel 'n metafoor is nie, word hierdie Skrifgedeelte wel deur die liggaam-metafoor beheers (Bukas-Yakabuul 1986:117). Paulus bou sy hele argument oor die aard, lewe en diens van die kerk om dié metafoor. Verder word dié metafoor deur ander metafore ${ }^{5}$ ondersteun (Bukas-Yakabuul 1986:118). Sommige navorsers meen dat die beeld van die kerk as die liggaam van Christus letterlik opgeneem moet word (Mjekula 1989:31; kyk ook Lee 2006:1-2). Maar dit sou neerkom op 'n verabsolutering van een Pauliniese beeld van die kerk ten koste van ander (die kerk as bruid [Ef 5:22-32], olyfboom [Rom 2] en tempel van die Here [1 Kor 3:6]).

Interpretasies van 1 Korintiërs 12 in die konteks van die liggaammetafoor is uiteenlopend (Bukas-Yakabuul 1986:119). Tog is die sleutel tot die verstaan van Paulus se gebruik van die liggaam-metafoor die gedagte van "een en baie" (Bukas-Yakabuul 1986:258). In hierdie gedagte word die voorwaarde van liefde vir mekaar ten einde die kerk as die liggaam van Christus op te bou, saamgevat. Hierdie goue draad wat deur 1 Korintiërs 12 tot 14 loop, loop ook deur die Grieks-Romeinse en Joods-Christelike gebruik van die metafoor.

Paulus se doel met die gebruik van die liggaam-metafoor is om gelowiges op te roep om te groei in liefde en eenheid en om die kerk, die liggaam van Christus, op te bou (1 Kor 13 en 14:12). Tog poog hy nie om 'n sistematiese of volledige verduideliking of selfs beskrywing van die kerk as

\footnotetext{
${ }^{5}$ Voorbeelde van sodanige ondersteunende metafore is "... ons is almal van die een Gees deurdrenk" (1 Kor 12:13), "Nou kyk ons nog in 'n dowwe spieël ..." (1 Kor 13:12) en "... het ek 'n stuk klinkende metaal, 'n galmende simbaal geword" (1 Kor 13:1) (NAB).
} 
liggaam te gee nie (Bukas-Yakabuul 1986:256). Hy gebruik eerder die metafoor om grense te stel vir die selfbegrip van die kerk in Korinte - die gemeente word gekonfronteer met die teenstrydighede tussen hulle leefstyl en 'n leefstyl wat by die liggaam van Christus pas. Enkele voorbeelde is verdeeldheid in die gemeente (1 Kor 3:1-9), seksuele losbandigheid (1 Kor 5), die verhouding tussen man en vrou (1 Kor 11:2-16) en onreëlmatighede by die nagmaal (1 Kor 11:17-34).

In 1 Korintiërs 12-14 beklemtoon Paulus juis die eenheid te midde van verskeidenheid van die gemeente ten einde die twis in die gemeente oor die relatiewe waarde van die gawes van die Gees aan te spreek (Martin 1995:87). Paulus self, en sekere lidmate in die gemeente, plaas 'n hoë premie op die spreek in tale, maar juis die hoë profiel daarvan skep probleme. Paulus ontken dus nie die bestaan van klasseverskille nie, selfs nie in die kerk nie (Meeks 1983:90). Hy gebruik egter die liggaam-metafoor om 'n ommekeer in die hiërargiese beskouing van die liggaam in sy tyd te weeg te bring. Binne die liggaam van Christus is daar geen plek vir verskille in status nie, omdat die individuele ledemate ewe noodsaaklik is vir die effektiewe funksionering van die liggaam (Martin 1995:92). Die noodsaak lê nie in die verskille in status nie, maar in die verskil van en komplementering in funksie (Schroer \& Staubli 2001:38).

Deur die gebruik van die metafoor dui Paulus ook aan dat die liggaam van Christus alle mense uit alle kulture insluit wat deur die Gees daartoe geroep word (Bukas-Yakabuul 1986:264). Die kerk se eenheid in Christus styg bo alle menslike onderskeidings uit (Du Plooy 1982:78).

Paulus se gebruik van die liggaam-metafoor is buitengewoon omdat dit dikwels gebruik word met ' $n$ konkrete toespeling op die menslike liggaam van Jesus, gekruisig en opgestaan tussen die dooies uit (Meeks 1983:89). Dit word deur die twee belangrikste Christelike rituele, naamlik die doop en die nagmaal bevestig.

\subsection{Paulus se gebruik vergelyk met dié van die antieke skrywers}

Die spesifieke gebruik van die liggaam-metafoor as verbeelding van die kerk as die liggaam van Christus is tipies Paulinies (Porthen 1991:39). Hy gebruik dit spesifiek in oproep-tekste in reaksie op die bedreiging van die eenheid van die kerk deur Gnostiese individualisme. In sy gebruik van die metafoor wyk Paulus egter in enkele opsigte af van die algemene gebruik daarvan (Porthen 1991:40):

- Die Hellenistiese metafoor van die liggaam en sy ledemate fokus op die eenheid van die ledemate te midde van verskeidenheid, maar 
Paulus gaan verder deur die kerk met behulp van die metafoor met die liggaam van Christus te identifiseer;

- In algemene gebruik verwys die metafoor na die samelewing in die algemeen, maar Paulus vereng die gebruik tot 'n bepaalde groep in die samelewing naamlik die kerk; en

- In Hellenistiese denke was die oorsprong van die eenheid van die liggaam die natuur, maar Paulus fundeer die eenheid in die doop met een Gees, die skepping van een kerk uit Jode en Grieke en die deelname in een geestelike sakrament naamlik die nagmaal, wat die eskatologiese werklikheid 'n teenwoordige werklikheid maak. Paulus lê die grondslag hiervoor in 1 Korintiërs 10:17: "Omdat dit een brood is, is ons, al is ons baie, saam een liggaam, want ons het almal deel aan die een brood."

\section{SAMEVATTING}

Dit is duidelik uit die voorafgaande dat die liggaam-metafoor in die Griekse, Latynse en Hebreeuse kulture bekend was. In al drie kulture is die metafoor op 'n groep mense, die staat, die gemeenskap of selfs die kosmos toegepas. Die gebruik van die metafoor oor kulturele grense heen dra dus daartoe by dat Paulus dit so effektief kon aanwend. Die menslike liggaam as metafoor vir die kerk van Christus en die verhoudings tussen die lede van die kerk was verstaanbaar vir bykans enige Griekse, Latynse of Hebreeuse spreker.

Dit blyk dat geen enkele bron as oorsprong vir Paulus se gebruik van die liggaam-metafoor aangedui kan word nie. Tog moes Paulus met die bestaande konsepte rondom die liggaam rekening hou en bestaande vooronderstellings daaragter oorneem of wysig ten einde sy eie doel met die liggaam-metafoor te bereik. Dit is duidelik dat die liggaam-metafoor deel vorm van die literêr-historiese konteks waarbinne Paulus die metafoor gebruik het. En hierdie feit het waarskynlik 'n invloed op sy keuse van metafoor gehad: één metafoor verstaanbaar vir Jode, Grieke en Romeine.

Paulus se gebruik van die metafoor as identifikasie van die verhouding tussen Christus en sy kerk en gelowiges onderling, is egter uniek. Sy gebruik fokus op die "eienaar" van die liggaam naamlik Christus en die werking van die Gees van Christus ín die liggaam. Daarmee gee Paulus 'n geloofsdimensie aan die metafoor wat nie by Hellenistiese en Romeinse skrywers teenwoordig was nie. 


\section{Literatuurverwysings}

Alexander, T D 1997. s v הוּרְיד. NIDOTTE.

Bukas-Yakabuul, B 1986. Pauline use of the metaphor of the body in 1 Corinthians 12-14: A paradigm study in the New Testament use of metaphor. PhD dissertation, Emory University.

Chisholm, R B 1997a. s v בָָָָָָּ NIDOTTE.

Chisholm, R B 1997b. s v שִׁאי. NIDOTTE.

Du Plooy, A le R 1982. Kerkverband: 'n Gereformeerd-kerkregtelike studie. ThD proefskrif, Potchefstroomse Universiteit vir Christelike Hoër-Onderwys.

Jewett, R 1971. Paul's anthropological terms: A study of their use in conflict settings. Leiden: Brill.

Josephus. Bellum Judaicum. Loeb Classical Library.

Lakoff, G \& Johnson, M 1980. Metaphors we live by. Chicago, IL: The University of Chicago Press.

Lee, M V 2006. Paul, the Stoics, and the body of Christ. Cambridge: Cambridge University Press.

Lewis, C T \& Short, C 1907. A Latin dictionary founded on Andrew's edition of Freund's Latin dictionary. Oxford: Clarendon Press.

Livius. Historiarum ab urbe condita. Loeb Classical Library.

Martin, D B 1995. The Corinthian body. New Haven, CT: Yale University Press.

Meeks, W A 1983. The first urban Christians: The social world of the apostle Paul. New Haven, CT: Yale University Press.

Mjekula, Z M 1989. Pauline teaching on the church as the body of Christ with special reference to the church in South Africa today. MA dissertation, University of Port Elizabeth.

Motyer, J A 1975. s v $\sigma \omega \hat{\mu \alpha}$. NIDNTT.

Ogilvie, R M 1965. A commentary on Livy Books 1-5. Oxford: Clarendon Press.

Philo. De Plantatione. Loeb Classical Library.

Plato. Respublica. Penguin Classics.

Porthen, P 1991. The body of Christ as a compound metaphor in the Pauline epistles. MTh dissertation, University of Durban-Westville.

Sandnes, K O 2002. Belly and body in the Pauline epistles. Cambridge: Cambridge University Press.

Schroer, S \& Staubli, T 2001. Body symbolism in the Bible. Collegeville, MN: The Liturgical Press.

Schweizer, E R 1992. s v Body. ABD.

Wikenhauser, A 1937. Die Kirche als der mystische Leib Christi nach dem Apostel Paulus. Münster: Aschendorffschen Verlagsbuchhandlung. 